\title{
Effect of moderate and severe drought stress on the pre-anthesis development and yield formation of oats
}

\author{
P. PELTONEN-SAINIO \\ University of Helsinki, Department of Crop Husbandry, \\ SF-00710 Helsinki, Finland
}

\begin{abstract}
Greenhouse experiments were conducted at the University of Helsinki, Department of Crop Husbandry in 1989 and 1990 to provide information on the effects of drought stress on the developmental rate of the panicle, formation and abortion of florets, and formation of yield components in two oat cultivars, both adapted to the northern marginal growing conditions.

Moderate water deficit and severe drought stress did not affect the developmental rate of the panicle, but the pre-anthesis and post-anthesis architecture changed considerably; leaves unrolled later, the number of green leaves was lower, the internodes lengthened less, and the inflorescence was shorter as a consequence of water deficit.

Drought stress decreased the number of fertile florets in the panicle significantly, in the lower clusters of branches in particular. In the cultivar "Puhti", $57 \%$ of the fertile florets aborted as a consequence of moderate drought stress and $89 \%$ as a result of severe drought stress when compared to well-watered individuals, while in "Virma", a cultivar of significantly higher yield potential, $80 \%$ and $90 \%$ of the fertile florets wilted, respectively. In addition, water deficit caused considerable losses in all the morphological characteristics measured. Further implications of these results for yield formation are discussed.
\end{abstract}

Index words: Avena sativa L., water deficit, development, yield potential, morphology, yield components

\section{Introduction}

Genome as well as environment determine the progress of development of cereal plants. The development of oats is known to be affected by temperature and photoperiod (e.g. Coffman and Frey 1961, Forlin 1987). Water deficit is, however, associated with high temperatures - a reason why drought stress is commonly noted as hastening not only ripening but also pre-anthesis inflorescence development. Within this context, the question of water stress is of special interest in Finnish growing conditions, as early summer drought (Mukula and Rantanen 1989), occurring exactly during the development of inflorescence, is a recurrent problem in southern and southwestern areas especially. In addition, oats re- 
quire more water than other cereals in order to produce a kilogram of dry-matter (GEISLER 1970), so that water deficit may severely limit the yield formation of oats.

The objectives of the present study were to evaluate the effects of moderate and severe water deficit on 1) the developmental rate of the panicle, 2) the formation and abortion of fertile florets, and 3) the formation of the oat stand and the yield components in two cultivars, "Puhti"' and "Virma", differing in yielding ability.

\section{Materials and Methods}

Greenhouse experiments were conducted at the University of Helsinki, Department of Crop Husbandry, in 1989 and 1990 in order to assess the effect of drought stress on the development and yield formation of two oat cultivars, "Puhti"' (introduced in 1978) and "Virma”' (introduced in 1988).

\section{Growing conditions}

Before sowing, the seeds were pre-germinated on blotting paper for two days in $20^{\circ} \mathrm{C}$ in order to assure steady emergence. Altogether 13 pre-germinated seeds were settled into each pot (volume 5 liters, $\varnothing 20 \mathrm{~cm}$ ) containing peat-vermiculite mixture (1:1), which was watered evenly before portioning to the pots. After emergence the number of oat individuals per pot was verified. From the unrolling of the first leaf to pollination, the pots were grouped into three treatments with 40 pots in each:

1) well-watered, as the pots were frequently top-watered and the $\mathrm{pF}$-value was continuously near field capacity (pF 2)

2) moderately water stressed, as the $\mathrm{pF}$ increased to 3.5 before top-watered

3) severely water stressed, as pF increased to 4 , near wilting point, until top-watered, and leaves evidently lost turgor.

As the oats pollinated, these three treat- ments were divided into the following treatments:

4) continuously well-watered ( $\mathrm{pF} 2)$

5) continuously moderate water deficit $(\mathrm{pF}$ $\leqslant 3.5)$

6) continuously severe water deficit $(\mathrm{pF} \leqslant 4)$

7) well-watered at pre-anthesis stage ( $\mathrm{pF} 2)$, moderately drought stressed after pollination $(\mathrm{pF} \leqslant 3.5)$

8) moderate pre-anthesis water deficit $(\mathrm{pF}$ $\leqslant 3.5)$, well-watered after pollination $(\mathrm{pF} 2)$

9) severe pre-anthesis water deficit $(\mathrm{pF} \leqslant 4)$, well-watered after pollination $(\mathrm{pF} 2)$.

The oats were fertilized every other week in connection with watering. The daylength was 18 hours, which corresponds to the daylength at latitude $60^{\circ} \mathrm{N}$ during the early part of the summer. The day and night temperatures were adjusted to $20^{\circ} \mathrm{C}$ and $17^{\circ} \mathrm{C}$, respectively.

\section{Measurements}

The development and growth of the panicle and the morphological traits were evaluated every other day from the one-leaf stage to pollination. The developmental stage of inflorescence was determined from eight individuals per treatment according to the letter scale (Table 1) introduced by ÅFORS et al. (1988), which is a modified version of the developmental scale of WADDINGTON et al. (1983). A certain developmental stage was reached when more than half of the individuals (i.e., five from eight) had attained the stage in question. Simultaneously, macro-morphological traits, such as the total number of leaves on the main stem, the number of green leaves on the main stem, the height of the uppermost ligule measured from the coleoptile node $(\mathrm{cm})$, the height of the uppermost node measured from the coleoptile node $(\mathrm{cm})$, and the length of inflorescence ( $\mathrm{mm})$, were also measured.

When the oats pollinated, the number of fertile florets, separately from each different cluster of branches, was evaluated from ten randomly sampled individuals per treatment. 
The fertility of the florets, i.e., the development of both carpel and stamens, was investigated using a stereo microscope and a scalpel.

When ripened oat individuals from each treatment were gathered by hand and carefully analyzed separately. The number of secondary tillers was measured from 100 plants per treatment. In addition, the plant height $(\mathrm{cm})$, number of grains per panicle (empty hulls were excluded), single grain size (mg), panicle weight $(\mathrm{g})$, phytomass $(\mathrm{g})$, and harvest index $(\%)$ were measured separately from the main stem and secondary tillers.

\section{Statistical analyses}

The significance of the differences in morphological traits and yield components between the watering treatments was examined by a one-way analysis of variance using the computer program MSTAT 4.0. The relation between the developmental stage and the effective temperature sum for different watering treatments was studied using linear regression analysis (MSTAT 4.0).

\section{Results}

Neither moderate water deficit nor severe drought stress affected the developmental rate of inflorescence in the cultivars examined when compared to the well watered group. Both "Puhti" and "Virma" pollinated simultaneously (Fig. 1) when the effective temperature sum was $770^{\circ} \mathrm{C}$ (the base temperature being $5^{\circ} \mathrm{C}$ ). As a consequence of moderate and severe water deficit, oats, however, ripened some 10 days earlier, thereby resulting in a considerably shortened grain-filling period.

When severely drought stressed, half of the panicle remained in the leaf sheath in both cultivars. In addition, the more severe the water deficit was, the shorter the inflorescence (Fig. 2 ). The effect of water deficit on the length of inflorescence was not observed until the developmental stages $\mathrm{O}-\mathrm{P}$.
Table 1. Micro-morphological scale for cereals.

\section{Letter $^{1}$ Description ${ }^{1,2}$}

code

\begin{tabular}{|c|c|}
\hline A & Vegetative cupola stage \\
\hline B & Transition apex \\
\hline $\mathrm{C}$ & Early double ridge stage \\
\hline D & Double ridge stage \\
\hline $\mathrm{E}$ & Triple mound stage (not detected in wheat) \\
\hline $\mathbf{F}$ & Glume primordium present \\
\hline C & Lemma and floret primordium present \\
\hline $\mathrm{H}$ & Stamen primordium present \\
\hline I & Pistil primodium present \\
\hline K & Carpel primodium present \\
\hline $\mathbf{L}$ & Carpel surrounded by enlarged stamens \\
\hline I & $\begin{array}{l}\text { Stylar canal closing, ovarian cavity still open } \\
\text { above }\end{array}$ \\
\hline $\mathrm{N}$ & $\begin{array}{l}\text { Stylar canal remaining as a narrow opening, two } \\
\text { short style primordia present }\end{array}$ \\
\hline $\mathrm{O}$ & $\begin{array}{l}\text { Styles begin elongating, still projecting (not de- } \\
\text { tected in wheat) }\end{array}$ \\
\hline $\mathbf{P}$ & Styles strongly elongating \\
\hline Q & $\begin{array}{l}\text { Stigmatic branches differentiating as swollen } \\
\text { cells on styles }\end{array}$ \\
\hline $\mathbf{R}$ & $\begin{array}{l}\text { Stigmatic branches elongating (not detected in } \\
\text { wheat) }\end{array}$ \\
\hline S & $\begin{array}{l}\text { Unicellular hairs differentiating on ovary walls, } \\
\text { stigmatic branches still elongating }\end{array}$ \\
\hline $\mathrm{T}$ & $\begin{array}{l}\text { Hairs on ovary wall strongly elongating, stig- } \\
\text { matic branches as well }\end{array}$ \\
\hline $\mathrm{U}$ & $\begin{array}{l}\text { Stigmatic branches form a tangles mass (not de- } \\
\text { tected in oats) }\end{array}$ \\
\hline V & $\begin{array}{l}\text { Style and stigmatic branches erect, stigmatic } \\
\text { hairs differentiating }\end{array}$ \\
\hline & $\begin{array}{l}\text { Stigmatic hairs well-developed, branches spread- } \\
\text { ing outward }\end{array}$ \\
\hline & $\begin{array}{l}\text { Styles curved outward and stigmatic branches } \\
\text { spread wide, pollen grains on well-developed } \\
\text { stigmatic hairs }\end{array}$ \\
\hline
\end{tabular}

1 according to Åfors et al. (1988)

${ }^{2}$ according to WADDINGTON et al. (1983)

Drought did not affect the total number of leaves on the main stem. When watered frequently, leaves unrolled earlier, but the maximum nı'mber of leaves was, however, eight in all treatments of both cultivars. Water deficit resulted in a reduced number of green leaves on the main stem already during the pre-anthesis development, but the effect of severe drought stress was not greater than that 

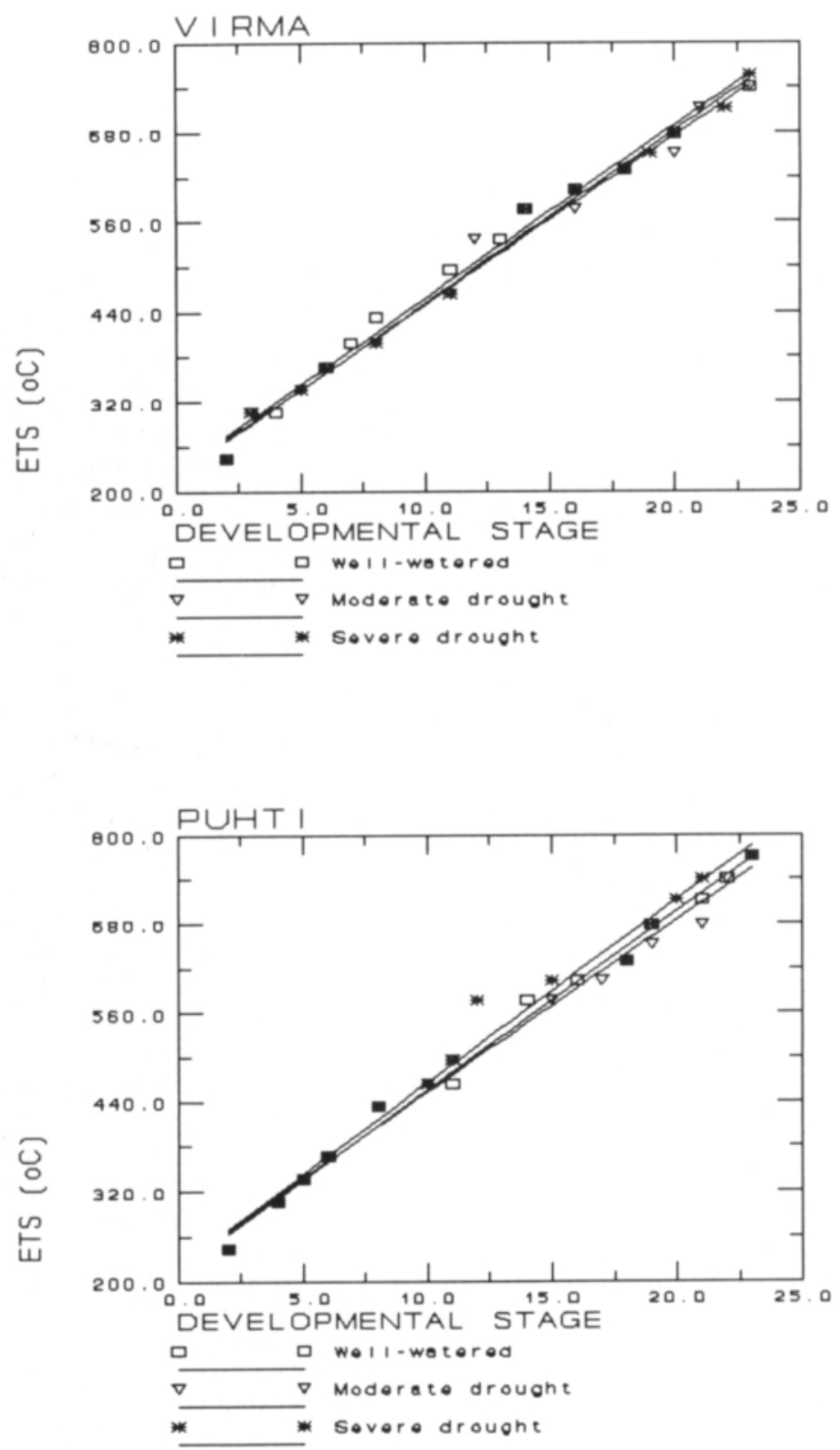

Fig. 1. Effect of water deficit on apical development $(1=$ developmental stage $\mathrm{A}, 2=\mathrm{B}, \ldots 23=\mathrm{Y})$.

of moderate drought stress. The difference between well-watered and moderately/severely water stressed main stems in the number of green leaves was observed already at the fourleaf stage, when the inflorescence was at the triple mound stage (E).

Drought stress retarded the lengthening of internodes. Differences between treatments in the height of the uppermost node were observable when carpel began to differentiate (stage K, Fig. 3). In addition, differences between treatments in the length of the uppermost ligule as measured from the coleoptile node were observable when "Virma" reached the developmental stage G and "Puhti”' stage $\mathrm{K}$. The oat cultivars examined, "Puhti" and 

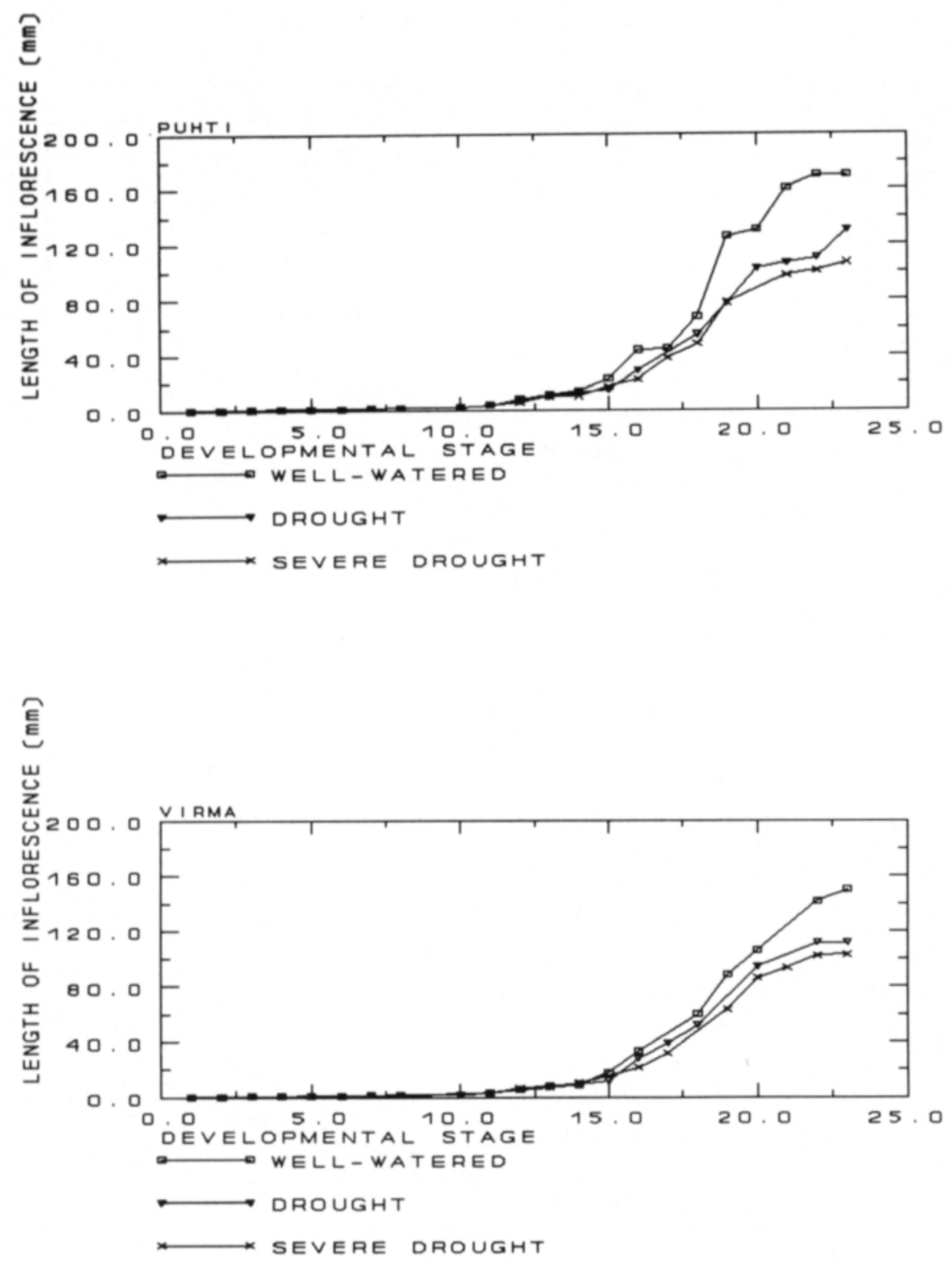

Fig. 2. Effect of water deficit on length of inflorescence $(1=$ developmental stage $\mathrm{A}, 2=\mathrm{B}, \ldots 23=\mathrm{Y})$.

"Virma", differed significantly $(\mathrm{P} \leq 0.01)$ from each other in yield potential. The number of fertile florets per panicle of the cultivar "Puhti"' was 72 when well-watered, while "Virma" produced 103 fertile florets. The number of fertile florets was 42 in "Puhti", and 50 in "Virma" under moderate drought stress, while under severe drought stress it was
36 and 42 , respectively (Table 2 ). Despite the higher floret number of "Virma", the rachis was some $2 \mathrm{~cm}$ shorter than in "Puhti".

Examining the most sensitive parts of the panicle for the effects of water deficit, it was found that "Puhti" produced an equal number of florets on the four uppermost clusters of branches, while "Virma" produced the 

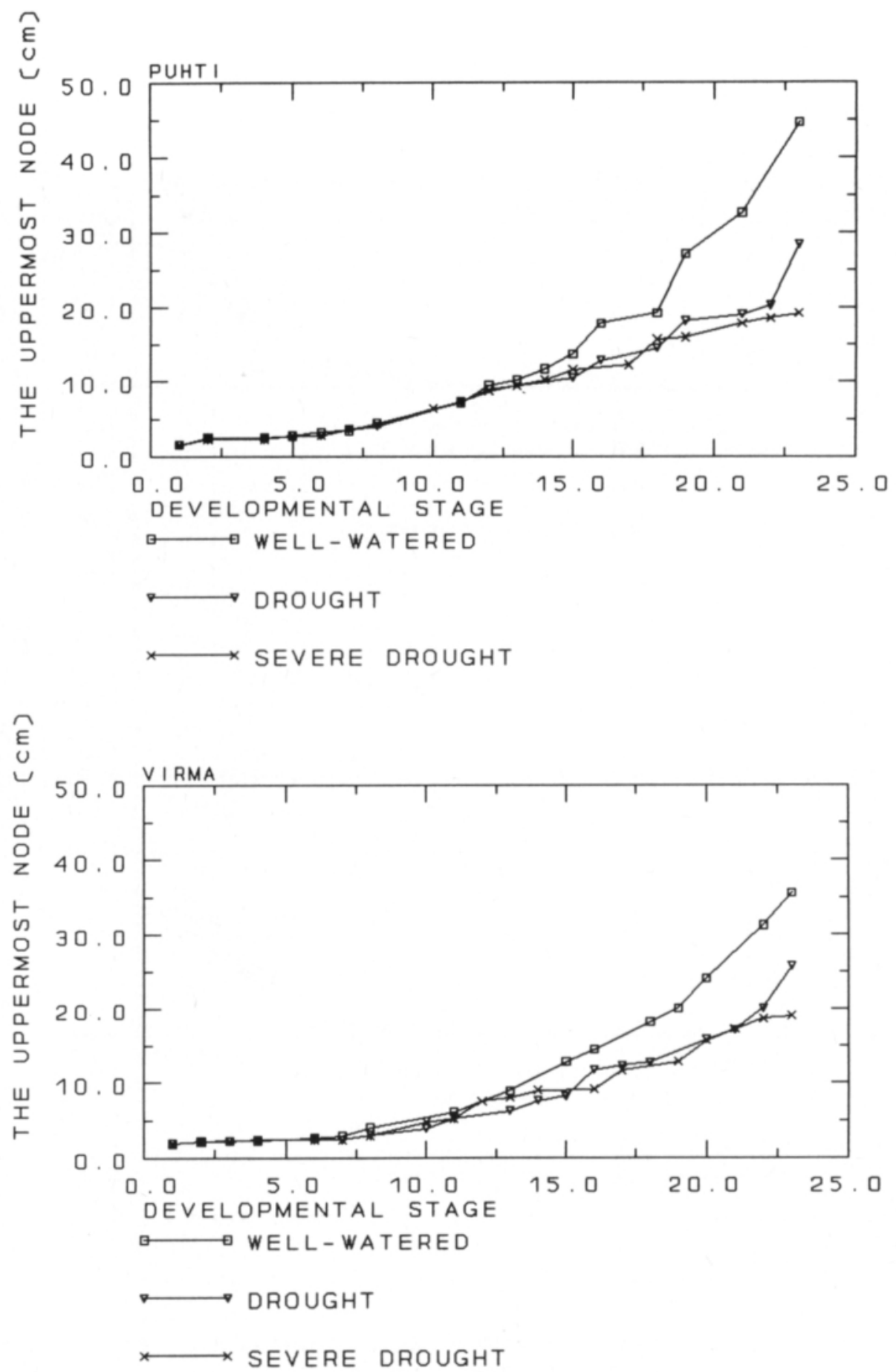

Fig. 3. Effect of water deficit on lengthening of internodes $(1=$ developmental stage $A, 2=B, \ldots 23=\mathrm{Y})$.

same floret number on the two uppermost clusters of branches in all treatments. Below that, the lower the cluster of branches was, the greater and more significant the reduction in the number of fertile florets as a consequence of moderate and severe water deficit 
(Table 2). When well-watered, about one third of the fertile florets aborted in both cultivars (Table 3). "Virma', a cultivar with clearly higher yield potential, suffered more than "Puhti" from water deficit; under moderate drought stress $80 \%$ of the fertile florets of "Virma" wilted, and under severe drought stress even $90 \%$. In 'Puhti”, the proportion of aborted florets was $57 \%$ and $89 \%$, respectively.

The oat stand was more abundant when watered frequently. When well-watered before pollination and then drought stressed at the post-anthesis phase, the number of grains per panicle and the harvest index were not clearly reduced in "Puhti", but single grain size, panicle weight, and phytomass decreased slightly (Table 4). Reductions of cultivar "Virma" in all the yield components examined were stronger. The differences between treatments in the morphological characteristics examined were highly significant.

The ability of the oat cultivars to compensate for yield losses by the production of secondary tillers was limited. The number of secondary tillers in "Puhti" was two as a consequence of both moderate drought and severe water deficit, and two and three in "Virma", respectively (Table 4). When drought stressed at the pre-anthesis phase and frequently watered after pollination, the production of secondary tillers did not increase. Both

Table 2. Number of fertile florets in different clusters of branches in panicle.

\begin{tabular}{|c|c|c|c|c|c|c|c|c|c|c|c|c|c|c|}
\hline \multirow{3}{*}{$\begin{array}{l}\text { Cluster of } \\
\text { branch }^{1}\end{array}$} & \multicolumn{7}{|c|}{ Puhti } & \multicolumn{7}{|c|}{ Virma } \\
\hline & \multicolumn{2}{|c|}{$\begin{array}{c}\text { well- } \\
\text { watered }\end{array}$} & \multicolumn{2}{|c|}{$\begin{array}{c}\text { moderate } \\
\text { drought }\end{array}$} & \multicolumn{3}{|c|}{$\begin{array}{c}\text { severe } \\
\text { drought }\end{array}$} & \multicolumn{2}{|c|}{$\begin{array}{c}\text { well- } \\
\text { watered }\end{array}$} & \multicolumn{2}{|c|}{$\begin{array}{c}\text { moderate } \\
\text { drought }\end{array}$} & \multicolumn{3}{|c|}{$\begin{array}{l}\text { severe } \\
\text { drought }\end{array}$} \\
\hline & NF & ratio & $\mathrm{NF}$ & ratio & $\mathrm{NF}$ & ratio & & NF & ratio & NF & ratio & NF & ratio & \\
\hline 1 & 1 & 100 & 1 & 100 & 1 & 100 & ns & 1 & 100 & 1 & 100 & 1 & 100 & ns \\
\hline 2 & 2 & 100 & 2 & 100 & 2 & 100 & ns & 2 & 100 & 2 & 100 & 2 & 100 & ns \\
\hline 3 & 3 & 100 & 3 & 100 & 3 & 100 & ns & 3 & 100 & 2 & 67 & 2 & 67 & $*$ \\
\hline 4 & 4 & 100 & 4 & 100 & 4 & 100 & ns & 6 & 100 & 4 & 67 & 3 & 50 & $* *$ \\
\hline 5 & 9 & 100 & 7 & 78 & 6 & 67 & $*$ & 10 & 100 & 6 & 60 & 7 & 70 & $* * *$ \\
\hline 6 & 14 & 100 & 9 & 64 & 7 & 50 & $* * *$ & 16 & 100 & 10 & 63 & 9 & 56 & $* * *$ \\
\hline 7 & 18 & 100 & 8 & 44 & 7 & 39 & $* * *$ & 28 & 100 & 12 & 43 & 9 & 32 & $* * *$ \\
\hline 8 & 21 & 100 & 8 & 38 & 6 & 29 & $* * *$ & 37 & 100 & 13 & 35 & 9 & 24 & $* * *$ \\
\hline $\begin{array}{l}\text { Total number } \\
\text { of florets }\end{array}$ & 72 & 100 & 42 & 58 & 36 & 50 & $* * *$ & 103 & 100 & 50 & 49 & 42 & 41 & $* * *$ \\
\hline
\end{tabular}

1 the uppermost branch corresponds to number 1

$\mathrm{NF}=$ number of fertile florets

$\mathrm{ns}=$ non-significant difference between treatments, ${ }^{*}=\mathrm{P} \leqslant 0.05,{ }^{* *}=\mathrm{P} \leqslant 0.01, * * *=\mathrm{P} \leqslant 0.001$

Table 3. Number of fertile florets and proportion of aborted florets in main stem.

\begin{tabular}{|c|c|c|c|c|c|c|c|c|c|c|}
\hline \multirow{3}{*}{$\begin{array}{l}\text { Watering } \\
\text { treatment }\end{array}$} & \multicolumn{5}{|c|}{ Puhti } & \multicolumn{5}{|c|}{ Virma } \\
\hline & \multicolumn{2}{|c|}{ Florets } & \multicolumn{2}{|c|}{ Grains } & \multirow[b]{2}{*}{ Abortion- $\%$} & \multicolumn{2}{|c|}{ Florets } & \multicolumn{2}{|c|}{ Grains } & \multirow[b]{2}{*}{ Abortion- $\%$} \\
\hline & Number & ratio & Number & ratio & & Number & ratio & Number & ratio & \\
\hline Well-watered & 72 & 100 & 46 & 100 & 36 & 103 & 100 & 66 & 100 & 36 \\
\hline $\begin{array}{l}\text { Moderate } \\
\text { drought }\end{array}$ & 42 & 58 & 18 & 39 & 57 & 50 & 49 & 10 & 15 & 80 \\
\hline $\begin{array}{l}\text { Severe } \\
\text { drought }\end{array}$ & 36 & 50 & 4 & 9 & 89 & 42 & 41 & 4 & 6 & 90 \\
\hline
\end{tabular}


Table 4. Effect of drought stress on morphological traits of oats.

\begin{tabular}{|c|c|c|c|c|c|c|c|c|c|c|c|c|c|}
\hline \multirow[t]{2}{*}{ Treatment } & \multicolumn{2}{|c|}{ No of grains } & \multicolumn{2}{|c|}{$\begin{array}{c}1000 \text { grain } \\
\text { weight }(\mathrm{g}) \\
\end{array}$} & \multicolumn{2}{|c|}{$\begin{array}{c}\text { Panicle } \\
\text { weight }(\mathrm{g})\end{array}$} & \multicolumn{2}{|c|}{$\begin{array}{c}\text { Phytomass } \\
\text { (g) }\end{array}$} & \multicolumn{2}{|c|}{$\begin{array}{c}\text { Harvest } \\
\text { index }(\%)\end{array}$} & \multicolumn{2}{|c|}{$\begin{array}{c}\text { Plant height } \\
(\mathrm{cm}) \\
\end{array}$} & \multirow{2}{*}{$\begin{array}{c}\text { No of } \\
\text { secondary } \\
\text { tillers }\end{array}$} \\
\hline & MS & ST & MS & ST & MS & ST & MS & ST & MS & ST & MS & ST & \\
\hline
\end{tabular}

Puhti:

\begin{tabular}{|c|c|c|c|c|c|c|c|c|c|c|c|c|c|}
\hline A & 46 & - & 41.1 & - & 1.85 & - & 4.17 & - & 43 & - & 117 & - & 0 \\
\hline B & 18 & 1 & 37.1 & 12.3 & 0.65 & 0.03 & 1.83 & 0.39 & 33 & 4 & 76 & 40 & 2 \\
\hline C & 4 & 0 & 20.3 & - & 0.13 & 0.00 & 1.08 & 0.16 & 8 & 0 & 46 & 17 & 2 \\
\hline D & 47 & - & 34.9 & - & 1.63 & - & 3.80 & - & 42 & - & 110 & - & 0 \\
\hline $\mathrm{E}$ & 18 & 1 & 36.5 & 16.6 & 0.63 & 0.03 & 1.74 & 0.72 & 34 & 3 & 70 & 61 & 2 \\
\hline F & 9 & 2 & 35.4 & 23.8 & 0.34 & 0.06 & 1.32 & 0.76 & 24 & 7 & 70 & 62 & 2 \\
\hline $\begin{array}{l}\text { Signifi- } \\
\text { cance }^{1}\end{array}$ & $* * *$ & $* * *$ & $* * *$ & $* * *$ & $* * *$ & $* * *$ & $* * *$ & $* * *$ & $* * *$ & $* * *$ & $* * *$ & $* * *$ & $* * *$ \\
\hline L.S.D. $5 \%$ & 4 & 0.4 & 3.0 & 3.8 & 0.15 & 0.01 & 0.26 & 0.19 & 3 & 1 & 3 & 5 & 0.2 \\
\hline \multicolumn{14}{|l|}{ Virma: } \\
\hline A & 66 & - & 30.2 & - & 2.03 & - & 4.31 & - & 46 & - & 96 & - & 0 \\
\hline B & 10 & 3 & 19.5 & 10.9 & 0.28 & 0.06 & 1.00 & 0.34 & 20 & 11 & 46 & 29 & 2 \\
\hline C & 4 & 1 & 13.9 & 4.4 & 0.10 & 0.01 & 0.75 & 0.35 & 10 & 2 & 35 & 31 & 3 \\
\hline D & 47 & - & 29.5 & - & 1.35 & - & 3.10 & - & 41 & - & 85 & - & 0 \\
\hline E & 14 & 6 & 27.0 & 28.5 & 0.37 & 0.20 & 1.22 & 0.70 & 26 & 24 & 50 & 44 & 2 \\
\hline F & 7 & 7 & 25.7 & 29.1 & 0.20 & 0.19 & 0.79 & 0.81 & 22 & 23 & 42 & 56 & 3 \\
\hline $\begin{array}{l}\text { Sifnifi- } \\
\text { cance }^{1}\end{array}$ & $* * *$ & $* * *$ & $* * *$ & $* * *$ & $* * *$ & $* * *$ & $* * *$ & $* * *$ & $* * *$ & $* * *$ & $* * *$ & $* * *$ & $* * *$ \\
\hline L.S.D. $5 \%$ & 5 & 1 & 3.0 & 2.8 & 0.15 & 0.03 & 0.26 & 0.08 & 4 & 3 & 3 & 4 & 0.3 \\
\hline
\end{tabular}

1 Significance of difference between treatments; $* * * \mathrm{P} \leqslant 0.001$, L.S.D. $5 \omega_{0}=$ least significant difference at the level of $5 \% \mathrm{MS}=$ main stem; $\mathrm{ST}=$ secondary tiller (average)

$\mathrm{A}=$ well-watered; $\mathbf{B}=$ moderate drought; $\mathbf{C}=$ severe drought $\mathbf{D}=$ well-watered and post-anthesis drought; $\mathrm{E}$ $=$ moderate drought, well-watered at post-anthesis phase; $\mathrm{F}=$ severe drought, well-watered at post-anthesis phase

continuously well-watered and well-watered before pollination then drought stressed oat stands consisted of solely uniculms.

\section{Discussion}

Water deficit considerably affects the architecture of a plant and plant stand, but results concerning the influence of drought stress on the developmental rate are more divergent. According to Angus and Moncur (1977), as a result of mild water stress wheat pollinated earlier, but as a consequence of severe water stress wheat pollinated later when compared to well-watered individuals. According to the present study, water deficit even severe stress (near wilting point) - did not clearly retard or hasten the developmental rate of the oat panicle and the oats pollinated simultaneously regardless of the watering treatment.
During recent years, interest in the specified timing of management practices, such as urea application and herbicide treatment, has increased (DARWinkel 1983, Thomson et al. 1984, Peltonen and Peltonen 1990, PeltoNEN 1991). This means the use of micro-morphological scales, such as introduced by W ADDINGton et al. (1983) and Åfors et al. (1988), instead of macro-morphological scales (e.g. LARGE 1954, ZadoKs et al. 1974) in determining the optimal moment for application. Evaluation of the developmental stage from the developing inflorescence demands, however, a stereo microscope, which limits its application by farmers. Therefore, more easily measured indirect methods for determining the developmental stage of the inflorescence have been investigated (e.g. TotTMAN 1977, Kirby and Appleyard 1984, Peltonen and Peltonen 1990). Several factors, however, considerably affect the formation of mor- 
phological traits. According to the present study, soil water deficit clearly affected the pre-anthesis morphological development. The number of leaves on the main stem differed in certain developmental stages depending on the availability of water. In addition, lengthening of the internodes and inflorescence were strongly retarded as a result of water deficit. Therefore, morphological characteristics are not suitable for use as the sole indirect indicators of the developmental stage of the inflorescence. Drought did not, however, retard or hasten the developmental rate of the panicle, but oats pollinated when the effective temperature sum was some $770^{\circ} \mathrm{C}$. The congruence of the regression lines in figure 1 indicates that the temperature sum might be a suitable indirect indicator of the developmental stage of the inflorescence, either alone or together with one or two morphological indicators. This question, however, requires more detailed research. In addition, on the basis of the present study, it is clearly more accurate for researchers to use the effective temperature sum instead of days from sowing and in some cases the developmental stage of the inflorescence instead of or together with macromorphological traits when presenting for example the time of appearance of disease symptoms or the time of pest colonization.

According to recent studies (LARSSON and GoRnY 1988, YADAVA and BhatT 1989), oat cultivars differ from each other in their sensitivity to drought stress and more emphasis has recently been directed to finding timesaving methods for the evaluation of drought resistance in breeding programs (e.g. LARSSON 1982, Barbour and Murphy 1984, CorbelliNi et al. 1988, PARleVliet 1988, Ritchie et al. 1990 ). According to the present study, "Virma", a cultivar of high yield potential, suffered stronger floret losses than "'Puhti". With frequent watering "Virma" produced $30 \%$ more fertile florets per panicle than "Puhti" and one third of the florets aborted in both cultivars. When "Virma" was stressed by a moderate water deficit the number of florets fell by $51 \%$, and with a severe water deficit by $59 \%$, while the reduction in the number of fertile florets in "Puhti" was $42 \%$ and $50 \%$, respectively. Differentiation of the carpel and stamens on the florets of the first developed parts of the panicle did not cease because of drought, but development of florets on branches differentiated later was interrupted, resulting in a lower number of fertile florets in the inflorescence in both cultivars. In addition, at the post-anthesis phase one third of the fertile florets did not fill into grains despite optimal water conditions. As a result of moderate water deficit and severe drought $57 \%$ and $89 \%$ of the fertile florets aborted in "Puhti" and $80 \%$ and $90 \%$ in “'Virma”, respectively.

As oats suffer from pre-anthesis drought, yield losses due to a decreased number of fertile florets in the inflorescence can be compensated by either higher grain weight or the production of secondary tillers. When the cultivar "Virma"' was well-watered after a pre-anthesis water deficit, it compensated yield losses slightly better than the less drought-affected "Puhti" by considerably increasing the single grain size and by producing one secondary tiller more, and, in addition, by producing about five grains more per each secondary tiller (Table 3). The present study, however, indicated that in long day conditions (daylength $18 \mathrm{~h}$ ), as in northern latitudes, the compensation of yield losses by the production of secondary tillers was not adequately effective and, as disadvantage, it retarded the ripening of the oat stand - by three weeks according to the present study - resulting in a considerable risk of crop losses and quality deterioration (Mukula and Rantanen 1989).

The best impression of drought resistance in cereals can be attained by comparing the yield of a cultivar when well-watered and when water stressed (YADAva and BHATT 1989, Ritchie et al. 1990). By measuring the drought resistance index ( $R$, LARSSON and GORNY 1988) on the basis of the panicle weight of well-watered and moderately water stressed oat individuals it was revealed that both cultivars had considerable yield losses, 
but of different magnitude, $\mathrm{R}_{\text {Virma }}$ being 0.14 and $R_{\text {Puhti }} 0.35$. Despite the lower yield potential, i.e., lower number of fertile florets per panicle, "Puhti"' produced almost twice as many grains per panicle as "Virma" under moderate water deficit. In addition, the reductions in plant height and phytomass in "Puhti" were lower than in "Virma"' (Table 3). According to the present study, it is possible to evaluate drought tolerance already after pollination by measuring and comparing the number of fertile florets per panicle in wellwatered and in water stressed oat individuals.
This method is time and space saving as the oat genotypes are cultivated only to the pollination stage. The evaluation of fertile florets using stereo microscope and a scalpel is a rapid method, too, after a little practice.

Acknowledgements. I am grateful to Ms Aino Peltola of the Laboratory of Hydrology and Water Resources Engineering, Otaniemi, for assistance and advice during the measurement of soil water retention curves and to Mr Ari Rajala and Ms Marja Komppa for assistance during this study. A research grant from Varma ja Pauli Sariolan Kasvinjalostussäätiő is gratefully acknowledged.

\section{References}

Angus, J.F. \& Moncur, M.W. 1977. Water stress and phenology in wheat. Aust. J. Agric. Res. 28: 177 -181 .

Barbour, N.W. \& MurPhy, C.F. 1984. Field evaluation of seedling root length selection in oats. Crop Sci. 24: $165-169$.

Coffman, F.A. \& Frey, K.J. 1961. Influence of climate and physiological factors on growth in oats. In Oats and Oat Improvement. F.A. Coffman (ed.) p. 420 -456 .

Corbellini, M., Boggini, G., Borgonovo, M., Cattaneo, M., Quassou, M. \& Borghi, B. 1988. Screening for heat and drought tolerance in bread wheat ( $T$. aestivum L.) by means of laboratory tests and field observations. In Cereal Breeding Related to Integrated Cereal Production. M.L. Jorna \& L.A.J. SlootMAKER (eds.) p. 82-86. Pudoc Wageningen.

DARWINKEL, A. 1983. Ear formation and grain yield of winter wheat as affected by time of nitrogen supply. Neth. J. Agric. Sci. 31: 211-225.

ForLIN, C. 1987. Ax- och vippanlagens utveckling i korn och havre. Sver. Utsädesför. Tidskr. 97: 209-215.

Geisler, G. 1970. Pflanzenbau in Stichworten. I Die Kulturpflanzen. Kiel. 144 p.

Kirby, E.J.M. \& Appleyard, M. 1984. Cereal plant development - assesment and use. In Nitrogen Requirement of Cereals. Ministry of Agriculture, Fisheries and Food. Reference Book 385. p. 21-39. London.

LARGE, E.C. 1954. Growth stages in cereals. Illustration of the Feekes scale. Plant Path. 3: 128-129.

LARSSON, S. 1982. A simple, rapid and nondestructive screening method useful for drought resistance in breeding of oats (Avena sativa L.). Z. Pflanzenzüchtg. 89: 206-221.

— \& GoRnY, A.G. 1988. Grain yield and drought indi-

ces of oat cultivars in field rain shelter and laboratory experiments. J. Agron. Crop Sci. 161: 277-286. Mukula, J. \& Rantanen, 0. 1989. Climatic risks to the yield and quality of field crops in Finland. VII Oats 1969-1986. Ann. Agric. Fenniae 28: 37-43.

PARleVliet, J.E. 1988. Problems with selection for drought tolerance. In Cereal Breeding Related to Integrated Cereal Production. M.L. Jorna \& L.A.J. Slootmaker (eds.) p. 78-81. Pudoc Wageningen.

Peltonen, J. 1992. Use of car developmental stage for timing supplemental nitrogen application to spring wheat. Crop Sci., in press.

- \& Peltonen, P. 1990. Effect of apical-timed urea spraying on yield components and quality properties of spring wheat (Triticum aestivum L.) in greenhouse experiments. Acta Agric. Scand. 40: 33-43. $33-43$.

Ritchie, S.W., Nguyen, H.T. \& Holaday, A.S. 1990. Leaf water content and gas-exchange parameters of two wheat genotypes differing in drought resistance. Crop Sci. 30: 105-111.

Thomson, W.J., Scragg, E.B. \& Matthews, S. 1984. The tolerance of winter barley to hormone based herbicides in relation to apical and morphological development. In Crop Protection in Northern Britain 1984. J.R. Cutler (ed.) p. 31-37.

Totrman, D.R. 1977. The identification of growth stages in winter wheat with reference to the application of growth-regulator herbicides. Ann. Appl. Biol. 87: 213-224.

Waddington, S.R., Cartwright, P.M. \& Wall, P.C. 1983. A quantitative scale of spike initial and pistil development in barley and wheat. Ann. Bot. 51: $119-130$.

YadAVA, R.B.R. \& Bhatt, R.K. 1989. Physiological 
evaluation of drought resistance in oats. J. Agron. Crop Sci. 163: 138-140.

Zadoks, J.C., Chang, T.T. \& KonzaK, C.F. 1974. A decimal code for the growth stages of cereals. Weed Res. 14: $415-421$.

Ảfors, M., Ohlander, L. \& Stendahl, F. 1988. Stråsădens utveckling I En litteraturstudie och beskrivn- ing av en skala för bestämning av stråsädens axrespective vippanlag. Sver. Lantbruksuniversitet. Inst. växtodlingslära. $75 \mathrm{p}$. Uppsala.

Ms received June 17, 1991

\section{SELOSTUS}

\section{Kuivuusstressin vaikutukset kauran kehitykseen ja sadonmuodostukseen}

\section{Pirjo Peltonen-Sainio}

\section{Kasvinviljelytieteen laitos \\ Helsingin yliopisto, $00710 \mathrm{Helsinki}$}

Helsingin yliopiston kasvinviljelytieteen laitoksella jărjestettyjen kasvihuonekokeiden tarkoituksena oli selvittăă kohtuullisen ja ankaran kuivuusstressin vaikutuksia kauran kehitykseen ja sadonmuodostukseen. Koejăsenină olivat kotimaiset kauralajikkeet "'Puhti"' ja "Virma".

Kuivuuden vaikutusta kauran pölyttymistă edeltäneeseen kehitykseen selvitettiin määrittämällă kahdeksasta kasviyksilőstă joka toinen päivă kukinnon kehitysvaihe, kukintoaiheen pituus, lehtilukumäără, nivelvălien pidentyminen, ja ylimmăn kielekkeen korkeus maanpinnasta arvioituna. Kuivuuden vaikutuksia sadonmuodostukseen tutkittiin maaărittămăllă fertiilien kukkien (sekả emi ettă heteet erilaistuneet) lukumaaără pölyttymishetkellă sekä laskemalla kasvustojen tuleennuttua sivuversojen lukumäärä, fytomassa, röyhypaino, röyhyn jyvălukumaaără, jyvăpaino, satoindeksi ja korrenpituus erikseen sekă paaăversosta ettă sivuversoista. Lisăksi arvioitiin kehittymăttă jăăneiden eli abortoituneiden kukkien osuus vertaamalla lopullista jyvămaaărăă pölytty- mishetkellă laskettuun kukkamäăräăn.

Tulokset osoittivat, ettả kuivuus ei nopeuttanut kauran kukinnon kehitystä, vaan kuivuuden ankaruudesta riippumatta kaurat pölyttyivăt, kun tehoisan lämpötilan summaa oli kertynyt noin $770^{\circ} \mathrm{C}$. Sekä kohtuullinen että ankara kuivuus nopeutti kuitenkin kasvustojen tuleentumista kymmenellä päivăllä. Lisäksi kuivuus heikensi tutkittuja satokomponentteja ja lyhensi kortta.

Lajikkeet erosivat toisistaan kyvyssään kestää kuivuusstressiä. "Virman" fertiileistă kukista $80 \%$ abortoitui kohtalaisen kuivuuden johdosta, kun "Puhdilla" abortoituneiden kukkien osuus oli 57 \%. "Virma" kuitenkin kykeni hivenen "Puhtia" paremmin kompensoimaan kasvukauden alkupuolen kuivuuden aiheuttamia menetyksiă tăyttămăllă jyvăt painavammiksi ja versomalla runsaammin. Jälkiversontaa voi pităả kuitenkin oloissamme selvăsti haitallisena sen aiheuttaessa kasvustojen epătasaista tuleentumista. 